JOURNAL OF PUBLIC HEALTH INNOVATION

VOL. 01 NO. 02 , JUNI 2021

DOI: $10.34305 /$ JPHI.V1I2.302
Ciptaan disebarluaskan di bawah

Lisensi Creative Commons Atribusi-NonKomersialBerbagiSerupa 4.0

\title{
HUBUNGAN LAMA KALA III PERSALINAN DENGAN KEJADIAN \\ PERDARAHAN PADA IBU POST PARTUM DI RSUD 45 KUNINGAN
}

\author{
Nita Ike Dwi Kurniasih, Cecep Heriana, Evi Soviyati, Ryan Apriyanti \\ STIKes Kuningan \\ nitaikedk@gmail.com
}

\begin{abstract}
Abstrak
Persalinan kala III merupakan bagian dari proses persalinan yang tidak bisa di pandang sebelah mata karena Angka Kematian Ibu di Indonesia masih tinggi salah satunya adalah perdarahan sebesar (42\%) dimana sebagian besar disebabkan oleh atonia uteri dan retensio plasenta. Penelitian ini bertujuan untuk mengetahui Hubungan Lama Kala III Persalinan Dengan Kejadian Perdarahan Pada Ibu Post Partum di RSUD 45 Kuningan Kabupaten Kuningan. Jenis penelitian yang digunakan adalah penelitian analitik dengan rancangan kohort retrospektif menggunakan metode kuantitatif. Jumlah sampel ditentukan dengan perhitungan slovin sebanyak 92, dengan teknik pengambilan random sampling. Analisa data menggunakan analisa univariat dan bivariat dengan uji Chi Square.

Hasil analisis univariat menunjukan bahwa dari 92 ibu bersalin waktu lama kala III $\leq$ 15 menit sebanyak 64 orang $(69,6 \%)$, sedangkan yang mengalami perdarahan post partum sebanyak 21 orang (22.8\%). Uji Chi Square diperoleh nilai $\mathrm{p}$ value $=0,044<0,05$. Berdasarkan penelitian ini menunjukan bahwa terdapat hubungan lama kala III dengan kejadian perdarahan pada ibu post partum di RSUD 45 Kuningan Kabupaten Kuningan. Disarankan bagi tenaga kesehatan khususnya bidan lebih meningkatkan kualitas dalam prosedur penanganan persalinan terutama dalam penerapan manajemen aktif kala III untuk menurunkan angka kejadian pascapersalinan..
\end{abstract}

Kata kunci : lama kala III, Perdarahan, post partum

\section{Pendahuluan}

Keberhasilan upaya kesehatan ibu dapat dilihat dari indikator angka kematian ibu. Menurut World Health Organitation (WHO) wanita berusia 15 sampai 49 tahun sekitar 600.000 meninggal dunia setiap 
JOURNAL OF PUBLIC HEALTH INNOVATION

VOL. 01 NO. 02 , JUNI 2021

DOI: $\underline{10.34305 / \text { JPHI.V1I2.302 }}$

tahunnya karena mengalami komplikasi kehamilan dan persalinan. Kematian ibu di Negara berkembang pada tahun 2015 adalah 239 per 100.000 kelahiran hidup, sedangkan di Negara maju jauh lebih rendah yaitu 12 per 100.000 kelahiran hidup (WHO, 2018).

Lima penyebab kematian ibu terbesar di Indonesia yaitu pendarahan, Hipertensi Dalam Kehamilan (HDK), infeksi, partus lama atau macet, dan abortus. Kematian ibu di Indonesia masih didominasi oleh tiga penyebab utama kematian yaitu pendarahan, hipertensi dalam kehamilan dan infeksi. Pendarahan pasca persalinan adalah salah satu penyebab langsung kematian ibu, hampir seperempat dari semua kematian ibu di seluruh dunia yang melibatkan 150.000 kematian dalam satu tahun, terutama terjadi di negara berkembang. Sebagian besar dari kematian ibu $(88 \%)$ terjadi dalam 4 jam setelah persalinan, menandakan bahwa ini merupakan kejadian yang berkaitan erat dengan persalinan kala III (Prawiroharjo, 2012).

Menurut WHO banyak 99\% kematian ibu akibat masalah persalinan atau kelahiran terjadi di negara-negara berkembang. Rasio kematian ibu di negaranegara berkembang merupakan yang
Ciptaan disebarluaskan di bawah

Lisensi Creative Commons Atribusi-NonKomersialBerbagiSerupa 4.0

tertinggi dengan 450 kematian ibu per 100.000 kelahiran hidup jika dibandingkan dengan rasio kematian ibu di sembilan negara maju dan 51 negara persemakmuran. Sejumlah kasus kematian ibu sebanyak $81 \%$ terjadi akibat komplikasi selama hamil, bersalin dan $25 \%$ selama masa nifas. Upaya dalam penurunan kematian atau kesakitan itu tercantum dalam SDGs (Sustainable Develovment Goals). Ada 17 tujuan global dalam SDGs yang berkaitan dengan upaya penurunan kematian atau kesakitan ibu pada nomor 2 yaitu kesehatan yang baik dan kesejahteraan (Wardah, 2016).

Pendarahan post partum menjadi penyebab utama kematian ibu di Indonesia dan robekan jalan lahir merupakan penyebab kedua perdarahan setelah atonia uteri yang terjadi pada hampir persalinan pertama dan tidak jarang juga pada persalinan berikutnya (Prawiroharjo, 2012). Faktor penyebab perdarahan yang paling sering yaitu atonia uteri serta retensio plasenta, adapun penyebab lain yaitu laserasi serviks atau vagina, ruptur uteri, inversio uteri dan infeksi nifas.

Perdarahan post partum juga bisa terjadi karena riwayat persalinan yang buruk, diantaranya pada saat proses kelahiran plasenta. Pelepasan plasenta 
JOURNAL OF PUBLIC HEALTH INNOVATION

VOL. 01 NO. 02 , JUNI 2021

DOI: $\underline{10.34305 / \text { JPHI.V1I2.302 }}$

merupakan bagian dari manajemen kala III dalam persalinan yang bertujuan untuk menghasilkan uterus secara spontan berkontraksi keras dengan isi yang sudah kosong, karena bayi sudah lahir sehingga mempercepat kelahiran plasenta dan dapat mencegah atau mengurangi pendarahan postpartum (Prawiroharjo, 2012). Faktor yang mempengaruhi lamanya kala III diantaranya umur dan paritas, dimana umur yang belum produktif sangat mempengaruhi proses persalinan, sedangkan pada paritas mempengaruhi efektifitas uterus dalam semua tahapan persalinan. Lamanya kala III normal adalah 5 sampai 15 menit (Sisca Alviani et al., 2018).

Penegangan Tali pusat Terkendali PTT dengan cara satu tangan diletakan pada korpus uterus tepat di atas simfisis pubis, jika menggunakan mangemen aktif kala III tetap tidak ada tanda pelepasan plasenta setelah 15 menit, maka ulangi pemberian oksitosin 10 unit IM dosis kedua, dalam jarak waktu 15 menit dari pemberian
Ciptaan disebarluaskan di bawah

Lisensi Creative Commons Atribusi-NonKomersialBerbagiSerupa 4.0

oksitoksin dosis pertama (Nurasiah et al., 2014).

\section{Metode}

Penelitian ini menggunakan jenis penelitian analitik dengan rancangan kohort retropektif yang digunakan untuk mengetahui hubungan lama kala III persalinan dengan kejadian perdarahan ibu post partum di RSUD 45 Kuningan. Populasi dalam penelitian ini adalah ibu bersalin di RSUD 45 Kuningan, dengan jumlah sampel ditentukan dengan perhitungan slovin sebanyak 92, dengan teknik pengambilan sampel menggunakan random sampling. Pengumpulan data dilakukan observasi dengan menggunakan daftar ceklis. Analisa data yang digunakan menggunakan analisa univariat dan bivariat dengan uji Chi Square.

\section{Hasil}

Analisa Univariat

Berikut disajikan tabel distribusi frekuensi univariat:

Tabel 1 Gambaran Distribusi Frekuensi Lama Kala III ibu bersalin dan perdarahan pascasalin persalinan Di RSUD 45 Kuningan

\begin{tabular}{lll}
\hline Vaiabel & Frekuensi (f) & Persentase (\%) \\
\hline
\end{tabular}


JOURNAL OF PUBLIC HEALTH INNOVATION

VOL. 01 NO. 02 , JUNI 2021

DOI: $10.34305 /$ JPHI.V1I2.302
Ciptaan disebarluaskan di bawah

Lisensi Creative Commons Atribusi-NonKomersialBerbagiSerupa 4.0

\begin{tabular}{lcc}
\hline Lama Kala III & & \\
$\leq 15$ menit & 64 & 69,6 \\
$15-30$ menit & 21 & 22,8 \\
$\geq 30$ menit & 7 & 7,6 \\
\hline Jumlah & 92 & $\mathbf{1 0 0}$ \\
\hline Perdarahan & 21 & 22,8 \\
$\geq 500 \mathrm{cc}$ & 71 & 77,2 \\
$<500 \mathrm{cc}$ & $\mathbf{9 2}$ & $\mathbf{1 0 0}$ \\
\hline Jumlah & & \\
\hline
\end{tabular}

Tabel 2 Hubungan Antara Lama Kala III persalinan dengan Kejadian Perdarahan Ibu Post Partum di Rumah Sakit 45 Kuningan Kabupaten Kuningan

\begin{tabular}{|c|c|c|c|c|c|c|c|}
\hline \multirow{3}{*}{ Lama Kala III } & \multicolumn{4}{|c|}{$\begin{array}{c}\text { Kejadian Perdarahan Post } \\
\text { Partum }\end{array}$} & \multirow{2}{*}{\multicolumn{2}{|c|}{ Jumlah }} & \multirow{3}{*}{$\rho_{\text {value }}$} \\
\hline & \multicolumn{2}{|c|}{ Anemia } & \multicolumn{2}{|c|}{ Tidak Anemia } & & & \\
\hline & $\mathrm{Ya}$ & $\%$ & Tidak & $\%$ & $\mathbf{N}$ & $\%$ & \\
\hline$\leq 15$ menit & 11 & 17.2 & 53 & 82.8 & 64 & 100 & \\
\hline 15-30 menit & 6 & 28.6 & 15 & 71.4 & 21 & 100 & 0,044 \\
\hline$\geq 30$ menit & 4 & 57.1 & 3 & 42.9 & 7 & 100 & \\
\hline
\end{tabular}

\section{Pembahasan}

Kala III persalinan dimulai setelah bayi lahir sampai plasenta keluar. Biasanya plasenta lepas dalam waktu 6 sampai 15 menit setelah bari lahir dan lahir spontan atau dengan adanya tekanan dari fundus uteri (Nurasiah et al., 2014). Berdasarkan hasil penelitian menunjukan bahwa lama kala III persalinan cenderung lebih banyak dengan waktu $\leq 15$ menit dibandingkan dengan waktu lama kala III $\geq 30$ menit. Hal ini disebabkan karena adanya faktor-faktor yang mempengaruhi lamanya kala III diantaranya kelainan dari uterus, dari palsenta dan sifat plasenta pada uterus, adapun karena kesalahan manajemen kala III yang kurang tepat sehingga menyebabkan serviks kontaksi dan menahan plasenta serta pemberian anastesi. 
JOURNAL OF PUBLIC HEALTH INNOVATION

VOL. 01 NO. 02 , JUNI 2021

DOI: $\underline{10.34305 / \text { JPHI.V1I2.302 }}$

Hasil penelitian juga menunjukan sebanyak 21 orang $(22.8 \%)$ yang mengalami perdarahan dan sebagian besar 71 orang $(77.2 \%)$ tidak mengalami perdarahan pasca persalinan. Perdarahan pasca persalinan merupakan perdarahan pervaginam yang melebihi $500 \mathrm{ml}$ melalui jalan lahir yang terjadi selama atau setelah persalinan kala III. Pada praktisnya tidak perlu mengukur jumlah perdarahan sampai sebanyak itu sebab menghentikan perdarahan lebih dini akan memberikan prognosis lebih baik. Apabila terdapat perdarahan lebih dari normal, bahkan sampai terjadi perubahan tanda vital (kesadaran menurun, pucat, sesak nafas, serta tensi $<90 \mathrm{mmHg}$ dan nadi $>100 /$ menit maka penanganan harus segera dilakukan (Nurjanah et al., 2013)

Berdasarkan hasil penelitian menunjukan bahwa terdapat ada hubungan signifikan antara hubungan lama kala III persalinan dengan kejadian perdarahan ibu post partum di Rumah Sakit 45 Kuningan Kabupaten Kuningan dengan nilai $p$ 0,044. Hasil penelitian menunjukan ibu bersalin dengan lama kala III $\leq 15$ menit yang tidak mengalami perdarahan post partum sebanyak 82,8\%, lama kala III 15-30\% menit yang tidak mengalami perdarahan post partum sebanyak $71,4 \%$ dan lama kala
Ciptaan disebarluaskan di bawah

Lisensi Creative Commons Atribusi-NonKomersialBerbagiSerupa 4.0

III $\geq 30$ menit yang tidak mengalami perdarahan post partum sebanyak $42,9 \%$. Ibu bersalin dengan lama kala III $\leq 15$ menit yang mengalami perdarahan post partum sebanyak $17,2 \%$, lama kala III 15$30 \%$ menit yang mengalami perdarahan post partum sebanyak $28,6 \%$ dan lama kala III $\geq 30$ menit yang mengalami perdarahan post partum sebanyak $57,1 \%$.

Semakin cepat lama kala III persalinan akan semakin mengurangi kejadian perdarahan pada ibu post partum. Rata-rata pelepasan plasenta yaitu $5-15$ menit, resiko perdarahan akan meningkat ketika kala III lebih dari 30 menit (Sisca Alviani et al., 2018).

Plasenta lepas dalam waktu 6 sampai 15 menit setelah bari lahir dan lahir spontan atau dengan adanya tekanan dari fundus uteri. Jika plasenta tidak lepas setelah melakukan penegangan tali pusat setelah 15 menit maka lakukan pengulangan pemberian oksitosin $10 \mathrm{IU}$ secara IM yang kedua (Prawiroharjo, 2012). Adapun plasenta yang tidak lahir dalam 30 menit setelah bayi lahir disebut retensio uteri, namun bila dalam 30 menit belum lepas sama sekali tidak akan terjadi perdarahan, tapi bila sebagian plasenta sudah lepas akan terjadi perdarahan dan ini 
JOURNAL OF PUBLIC HEALTH INNOVATION

VOL. 01 No. 02 , JUNI 2021

DOI: $\underline{10.34305 / \text { JPHI.V1I2.302 }}$

merupakan indikasi untuk segera mengeluarkannya (Mochtar, 2012).

Lama kala III persalinan bisa dipengaruhi oleh berbagai faktor-faktor yaitu diantaranya kelainan dari uterus, dari plasenta dan sifat plasenta pada uterus, adapun karena kesalahan manajemen kala III yang kurang tepat sehingga menyebabkan serviks kontraksi dan menahan plasenta serta pemberian anastesi. Sebagian besar ibu bersalin dengan lama kala III $\leq 15$ menit 64 orang dan sebagian besar ibu post partum yang mengalami perdarahan sebanyak 21 orang dari 92 responden, maka dari itu semakin cepat lama kala III akan mengurangi kejadian perdarahan ibu post partum. Namun dilihat dari data yang diperoleh lamanya kala III bisa dipengaruhi oleh usia yang terlalu muda dan terlalu tua. Adapun gravida juga mempengaruhi karena terlalu sering melahirkan tempat implantasi plasenta kemungkinan menjadi salah satu faktor lamanya kala III persalinan yang menyebabkan perdarahan post partum.

\section{Kesimpulan}

Hasil analisis univariat menunjukan bahwa dari 92 ibu bersalin waktu lama kala III $\leq 15$ menit sebanyak 64 orang $(69,6 \%)$, sedangkan yang mengalami perdarahan post
Ciptaan disebarluaskan di bawah

Lisensi Creative Commons Atribusi-NonKomersialBerbagiSerupa 4.0

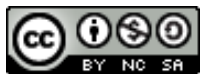

partum sebanyak 21 orang $(22.8 \%)$. Uji Chi Square diperoleh nilai $\mathrm{p}$ value $=0,044<$ 0,05. Berdasarkan penelitian ini menunjukan bahwa terdapat hubungan lama kala III dengan kejadian perdarahan pada ibu post partum di RSUD 45 Kuningan Kabupaten Kuningan. Disarankan bagi tenaga kesehatan khususnya bidan lebih meningkatkan kualitas dalam prosedur penanganan persalinan terutama dalam penerapan manajemen aktif kala III untuk menurunkan angka

kejadian pascapersalinan.

\section{Daftar Pustaka}

Mochtar, R. (2012). Sinopsis Obstetri. Jakarta : EGC.

Nurasiah, A., Rukmawati, A., \& Badriah, D. L. (2014). Asuhan kebidanan Persalinan Normal bagi Bidan. Bandung : Refika Aditama.

Nurjanah, S. ., Siti, A. M., \& Laelatul, D. B. (2013). Asuhan Kebidanan Postpartum Dilengkapi dengan Asuhan Kebidanan Post Sectio Caesarea. Bandung : Refika Aditama.

Prawiroharjo, S. (2012). Ilmu Kebidanan. Jakarta : Bina Pustaka

Sisca Alviani, E., Wijaya, M., \& Kurnia Aprilliani, I. (2018). Gambaran Lama Waktu Pelepasan Plasenta Dengan Manajemen Aktif Kala III Dan Masase Fundus Setelah Bayi Lahir Di Rsud Kelas B Kabupaten Subang. Jurnal Sistem

Kesehatan, 3(4). 
JOURNAL OF PUBLIC HEALTH INNOVATION

VOL. 01 NO. 02 , JUNI 2021

DOI: $\underline{10.34305 / \text { JPHI.V1I2.302 }}$

https://doi.org/https://doi.org/10.24198 /jsk.v3i4.18496

Wardah, F. (2016). Indikator Gender Harus Masuk dalam Pelaksanaan SDGs. http://www.djogjasumberberita.com/in
Ciptaan disebarluaskan di bawah Lisensi Creative Commons Atribusi-NonKomersialBerbagiSerupa 4.0

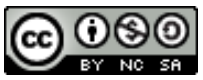

dicatorgenderharusmasukpelaksanaans dgs/

WHO. (2018). Maternal mortality. 